\title{
Asymmetrically Timely Loss Recognition and the Accrual Anomaly: Evidence From Pakistan's Non-financial Sectors
}

\author{
Amna Asim (Corresponding author) \\ Research Scholar, Karachi University Business School \\ University of Karachi, Karachi, Pakistan \\ E-mail: amnaasimshaikh@gmail.com \\ Danish Ahmed Siddiqui \\ Associate Professor, Karachi University Business School \\ University of Karachi, Karachi, Pakistan
}

Received: June 17, 2020

doi:10.5296/ijafr.v10i3.17203
Accepted: July 22, 2020

Published: August 7, 2020

URL: https://doi.org/10.5296/ijafr.v10i3.17203

\begin{abstract}
An important role of Conditional conservatism is to align the timely expense recognition of revenue generated in terms of losses compared to the profit over negative components of accruals. Accrual anomaly shows asymmetric differential persistence for accruals and cash flows in years of economic gains rather than losses. The aim of this study to determine the asymmetric timely loss recognition and accrual anomaly of the non-financial firms listed at Pakistan Stock exchange (PSX). Top volume non-financial firms listed at PSX were taken for this study over a period of 2011 to 2018 . The direct implication of this research on the pattern of pricing of accrual component of earning exhibits positive relationship of excess returns with accruals and stock returns; whereas negative relationship with earnings, market capitalization and indicator variable of profit firms. Overall, research result is consistent with Konstantinidi et al. (2015), the accrual effect on stock return is existent for earnings generated firms, while not apparent for loss firms. This evidence provides relevant information on the aspects of accrual anomaly and its association with the variables of conditional conservatism on the pricing of accrual during the profit years.
\end{abstract}




\section{Macrothink}

International Journal of Accounting and Financial Reporting

Keywords: Naive earnings fixation, Excess returns, Accrual anomaly, Earning persistence, Free cash flows, Conditional conservatism

\section{Introduction}

\subsection{Background to the Study}

Generally, it would be ideal for a company to follow accounting conservatism to stop these projects that would become unprofitable in the long run. By contrast, however, managers somehow operating those projects for the purpose of their empire-building motivations and employment horizon (Jensen, 1996; Ball, 2001).

Conditional conservatism is also referred to as asymmetrical timely loss recognition in the domain of financial reporting that has been placed in US GAAP Generally Accepted Accounting Principles as a measure of profit. Take, for instance, the amount of goodwill entity's capacity (ASC 350, FASB 2009b), market accounting or lower cost for a complete list of accounts (ASC 330, FASB 2009a) and asset impairments (ASC 360-10-35). These accordingly conservative accounting practices require early recognition of losses against profits through temporary negative adjustments (Basu 1997; Aier et al. 2014; Ball et al. 2013; Patatoukas et al. 2016). It implies that timely loss recognition is asymmetrical in the context of build-up items that are dependent on the factor whether the non-financial firms experience a loss or profit in the current year: the accrual ought to be not as much persistent for the years of loss as compared to years of profit.

The asymmetrical approach has profound implication for carrying out a research analysis on the future prediction of accrual price in different sectors over the period of loss and profit years. The basic idea of Sloan (1996) behind "accrual anomaly" is that stocks with high and increasing cumulative tend to have a low quality of earnings. On the other hand, stocks with low and decreasing accumulations tend to have a high quality of stock earnings. Having conditional conservatism, misjudged incomes fixation will only direct the lenders to estimate the higher returns in next-period income mostly in loss years. This leads the investors to miscalculate the non-financial firms, so Sloan's (1996) accrual anomaly, i.e. if the accruals and uneven stock returns are negatively related to each other which is more common in loss non-financial firms in comparison to profit non-financial firms.

By contrast, Konstantinidi reported in his study that accrual anomaly to be more pronounced for profit-generating non-financial firms while they do not seem to have sufficient evidence in the case of loss non-financial firms. Additionally, Konstantinidi et al. (2015) calculate the accrual as the variation between low cash flows from operating activities less profit after-tax or net income and found out that profit firms experience hedge return more positively from buy/sell and low/high accrual firms relative to loss non-financial firms while repeating the trading strategy.

\subsection{Problem Statement}

Prior researchers conducted on Accrual anomaly; investors tend to expect higher returns in loss years. In reality, firms with low capital undergo more profit. Then, accrual definitions 


\section{Mll Macrothink}

International Journal of Accounting and Financial Reporting

ISSN 2162-3082

2020, Vol. 10, No. 3

changed as the difference between earning less cash flow from cost associated with the operation of a firm. Because of the paucity of future returns in investors perspective related to the hedge return, there has been a dire need to get the clear picture of the stock market in Pakistan and relevant associated relationship of interlinked financial variables i.e. excess return, stock returns, accrual, earnings and market capitalization.

\subsection{Gap Analysis}

It is worth mentioning here, still to date no study examines in Pakistan whether the positive relationship of excess return with stock returns, accrual, earning and market capitalization while running a panel regression across loss and profit firm does exist. Accordingly, this study will form a strong basis for future studies to be implemented in other sectors.

\subsection{Research Objectives}

The aim of this study is to find out the existence of accrual anomaly in the top non-financial firms listed at Pakistan Stock Exchange. Firstly, the paper examines the accrual anomaly yearly manner by taking sample average time series distribution in a decile portfolio. Secondly, existence of accrual anomaly and asymmetrical timely recognition of losses over subsamples of loss and profit firms. Then, the relationship was further explored by interlinked financial variables.

\subsection{Significance}

Based on the working of accounting conservatism, conservatism has the impact on accounting practices and financial reporting significantly at both country levels and corporate. Sterling (1970) referred conservatism as the important source of assessment in the field of accounting. Further studies have shown that accountants, suppliers, regulators, debtors, customers and shareholders took into the account of the approach of accounting conservatism in order to facilitate corporate governance and decreases agency costs which aids in decreasing information asymmetry. When this approach combined with corporate governance, conservatism not only reduces the risk of investment but also improves investment efficiency.

\subsection{Outline of the Study}

The rest of the study proceeds as follows. Section 2 review of literature. Section 3 theoretical framework. Section 4 defines sample construction. Section 5 gives evidence of stock return in an estimated manner basis on accruals. Section 6 gives evidence of differences in the frequency of non-financial profit firms over accruals based on portfolios. Section 7 gives differences in the accrual anomaly over subsample of non-financial loss and profit firms. Section 8 conclusion.

\section{Literature Review}

Research on conservatism has gained importance since its inception but predominately over a period of two decades and relevant for both financial analyst and accountants.

Supattarakul (2013), conducted a study on the persistence of earning and the market pricing, by using three components of earning persistence: abnormal accruals, normal accruals and 
cash flows by taking a sample of 2,743 non-financial firms yearly from over a period of 10 years from 1999-2009 of Thailand capital market. The results regarding persistence of earning show those components of earnings: abnormal accruals are the least sensitive to each year earnings and cash flows are more persistence with each year earnings. Obtaining market prices, they applied the Mishkin test (1983) which implied that Thailand capital market does not logically follow pricing of three components of earnings. Hence, Thailand capital markets underestimate the persistence of normal accruals and cash flows while overestimate the persistence of abnormal accrual.

Patatoukas (2015), did a study on Asymmetrically timely loss recognition and accrual anomaly by using Sloan's (1996) trading strategy to find out negative relationship between accruals and excess return by taking a sample of yearly 56,482 non-financial firms of NYSE, AMEX and NASDAQ over a period of 23 years from 1989 - 2011. Variables used in this study are accruals, cash flows, stock returns and earnings. They separated the firms based on the sign of earning to find out hedge return between profit and loss firms. Study finding revealed that this study is line with Sloan's i-e, hedge return is more in loss firms as compared to profit firms.

Artikis et al. (2019), conducted a study to determine the correlation between cash flows with future earnings and stock returns of both profit firms and loss firms. The sample comprises of 22,230 non-financial companies operating on the London Stock Exchange each year over a period of 24 years from 1989-2013. By following Fama and Macbeth (1973) cross sectional regression technique in the analysis of separate stocks, the outcomes of the study show that the effect of free cash flow on future profitability and stock return is more in the loss firms as compared to profit firms. Portfolio level investigation further evaluates the financial importance of regression outcomes. The excess return from a trading strategy to determine hedge return on free cash flows is more than twice as high in loss firms in proportion to profit firms.

Papanastasopoulos (2019), examines the net operating assets (NOA) anomaly in combined European capital market that comprises of non-financial firms of sixteen developed stock markets: United Kingdom, Austria, Spain, Denmark, Netherlands, Belgium, Italy, Switzerland, Germany, Finland, Portugal, Ireland, Sweden, France, Greece and the Norway. The sample comprises of yearly 72,180 firms over a period of 24 years from 1989-2013. The trading hedge return on NOA was used across loss and profit firms. In result, loss firms generate larger raw and abnormal return relative to profit generating firms.

Asare (2019), conducted a research to assess how the persistence of earnings and components of cash flow and accruals depends on the changed accrual ratio and abnormal accruals of Jones Model. The total sample comprised of yearly 62,298 firms, excluding financial firms over a period of 26 years from 1988 to 2014. In line with previous studies, cash flow is more persistent with accruals, earnings and earnings component. Despite the fact that, variation in the persistence of the higher decile of abnormal accruals is not very large than that of the accrual ratio is much larger, offering that the accrual ratio can be easy but useful measure of 
persistence of earnings and can include abnormal accruals as a measure of the size of persistence in the quality of earnings.

\section{Theoretical Framework}

\subsection{Accounting Conservatism}

Accounting conservatism is a broad dynamic term evolving with time. Firstly, conditional conservatism defined as

"Predicting no profits but, predicting all loses over time" Bliss 1924

Then, this definition is further modified by Devine (1963), linked this definition with the firm's performance and goals which helps in setting standards to be targeted over a period of time

In 1975, FASB referred conservatism as "cautious response to improbability... Estimation of paid or received amounts are mutually exclusive in the future, conditional conservatism guides the use of the less probable estimation."

Another study purported the accounting conservatism as the principal for the accountants must account the least probable figures for assets and the maximum probable figures for liabilities. Moreover, revenues must be recorded earlier than expenditures. This definition takes financial reporting into account and proposed that traditional conservatism is a characteristic of reporting financial statements (Watts et al. 1986).

While these explanations are valuable, but they do not seem to take into account the actual economic environment and make no distinction between different types of conservatism. Thus, conservatism is difficult to measure, and scientists reached to conflicting conclusions. Basu (1997) devised a new insightful model to measure the accounting conservatism. Both the definition and the model are widely accepted and used. He interprets further conservatism to understand the tendency of accountants to require a higher level of verification for the detection of good news compared to bad news in the financial statements. The result reflects bad news faster than good news based on conservative principles. This definition takes into account different types of economic income and emphasizes the timeliness of registering economic losses, known as conditional conservatism. Ball et al. (2000a) suggest that this definition in fact defines conservatism as the extent to which current accounting income asymmetrically takes economic losses into account relative to economic gains.

\subsection{Accrual Anomaly and Timely Loss Recognition}

Accrual anomaly stems from the association of managerial manipulation. As a measure of firm performance, higher variation in accrual anomaly is more noticed in net income in comparison to cash flow from operating activities (Sloan 1996). Thus, it can mislead the investor. Accruals are divided into two parts, a discretionary (abnormal) and a normal. Sloan et al. (1996) investigated whether the naïve earning fixation approach could be applied on investors involving independent auditors, sell-side stock analysts and financial intermediaries with published opinions. For that, Bradshaw et al., (2001) corroborate with the hypothesis 


\section{$\triangle$ Macrothink}

International Journal of Accounting and Financial Reporting

ISSN 2162-3082

2020, Vol. 10, No. 3

that investors do not seem to anticipate the issue of accruals. For example, in case of analyst's perspective, they tend to estimate the difference between forecast earnings and realized income would lead to negative correlation with accruals. As the error lines with zero, then it indicates that analysts should include the effect of accrual in their predictions are less likely to publish optimistic opinions. There are indications that analysts' predictions do not include information obtained from accruals by nearly $20 \%$ in reported earnings, leading to prediction errors (Bradshaw et al. 2001). In addition, tests have shown that auditors less likely to offer customized audit judgments for firms with a high accrual.

Regarding accountants, similar studies established the link that high margin companies seem to penalize from SEC for GAAP violations. The underlying hypothesis, auditors must comply with the GAAP rules and therefore there must be a positive correlation between companies with high accrual and revised opinions published by an accountant. If companies with high accrual no longer have an adjusted opinion, the accountants do not consolidate the information content of the accrual (Bradshaw et al. 2001; Dechow et al. 1995).

Pincus et al. (2007) applied the Sloan's (1996) hypothesis on the global scale. Finding of the study showed that accrual anomalies exists not simply in the American stock markets but also in Canada, France, India Switzerland, Hong Kong, Netherlands, United Kingdom, Germany, Malaysia, Indonesia, Australia, Taiwan, Spain, Denmark, Japan, Singapore, Italy, Thailand and the Sweden although to varying degrees.

Additionally, it explored a possible factor that influences the anomaly. The authors claim that many factors at the national level that could lead to a wrong estimation of returns. Here, countries with a tradition of common law, widespread following in the accounting of accrual and a lower sense of share ownership indicate towards the difference in anomalies (Pincus et al. 2007).

Xie (2001) uses the Mishkin test (1983), previously introduced in Sloan (1996) financial literature, to demonstrate that stock market underestimates the accrual's persistence, overpricing and mispricing of accruals are attributed to them. Author further explained the normal accruals are linked with fundamental of economics (changes in sales, investments, etc.) whereas discretionary accruals are linked with earning management and unusual circumstances of firms. After checking for unusual business activities (mergers and acquisitions, IPO, etc.), the author finds indications of manipulations of earning by the management.

Khan et al. in 2008, shed a light on the explanation of accrual anomalies. The author assert that equity markets does not reflect the mispricing of accrual. In fact, the difference of risk between low and high portfolios of accruals is the most important indicator of future returns. The claim of author has not been considered to test the deviation in the pricing of accruals. They used a new method of asset prices to curb the risk. Following the Campbell et al. in 2004, the Cahart four factor model considers the two factors, the future expected value of the return and dividend, are regarded as risk factors along with the traditional HML and SMB. The test errors rejected the Capital Asset Pricing Model, and the three-factor model from Fama et al. in 1993, while the Cahart four factor model was approved. The finding shows that expected value of the return of low and high build portfolios will average the realized return if the risk is adjusted 
using the ICAPM. Additionally, author provides the evidence that risk of liquidation correlates negatively with the future return. Instead, accruals are used to indicate documented financial and economic problems caused by their relationship.

Wu et al. (2010) considers accrual as investments in working capital to apply the optimal theory of investment. It stated that companies coordinate their finances to counteract changes in the cost of capital. The possible reason is the negative relationship of the capital cost (discounted prices) with the net present value. When the capital cost falls, the net present value of a project is more profitable, which leads to more investment, which increases the magnitude of accruals. On the other hand, higher capital costs lead to a lesser net present value and thus to a reduction in accruals and investments. Higher capital costs also lead to higher current returns (because share prices are rising). Thought, it also indicates the mean lower expected value of returns. Therefore, the forecasting of accruals for earnings increases subsequently with the differences of the return (current and past) and the accruals. Due to this reason, future returns have an inverse relationship with the accruals.

Papanastasopoulos (2014) also provided the evidence that differences in anomaly across countries in terms of culture, stock markets, and research results from analysts, investor protection and ownership structure explain the differences in the extent of the constructive deviation.

Srivastava et al. (2015) indicated that the excess return in accounting conservatism income enables board members, shareholders and lenders to identify unprofitable projects. It would allow the managers to stop such projects before significant value erosion occurs. In line with this idea, we believe that timely detection of losses increases the chance of completing unprofitable projects on time. By announcing that projects are delayed, managers also demonstrate that they cannot choose good projects and / or manage losses when projects become unprofitable.

\subsection{Hypothesis Development}

According to the Sloan's (1996) claim on the trend of current earnings will continue in near future appeared to be dependent on accrual component of earning and the size of cash. By contrast, stock prices do not seem to fully reflect the information obtained from accruals and cash flow component when investors naively fixate on earning. Hence, firms with low capital tends to achieve good quality of stock earning.

\section{H1: Investors tend to overestimate the accrual anomaly of profit generating firms mostly in loss years}

On closer analysis of Sloan's (1996) on an accrual anomaly by running the regression between the uneven stock return and accruals, finding of the study supports that these variables are negatively related to each other which is more pronounced in the case of loss non-financial firms in comparison to profit non-financial firms.

\section{H2: A negative relation exists between accruals and excess returns.}




\section{Mll Macrothink}

International Journal of Accounting and Financial Reporting

ISSN 2162-3082

2020, Vol. 10, No. 3

Konstantinidi et al. (2015) further explored the information on the asymmetric timely identification of losses revealed from the accruals and cash flows resulting from accounting conservatism (discretionary) over the sample of loss and profit firms. Their finding contradicts the Sloan's trading strategy by using the Mishkin test in order to provide valuable phenomena of naively earning fixation. Consequently, accrual anomaly is more noticed in profit-generating non-financial firms

\section{H3: Asymmetrical timely loss identification is most persistent for-profit years.}

\section{Sample Construction}

Annual accounting variables data was collected from investors lounge website and from annual reports of firms, stock returns data on weekly bases from investing website and market caps data of all-share index from Pakistan Stock Exchange (PSX).

\section{Definition of variables}

\begin{tabular}{ll}
\hline Variables & Definition \\
\hline $\boldsymbol{X}_{i t}$ & $\begin{array}{l}\text { Earnings are calculated as profit after tax per-share divided by average total } \\
\text { assets per-share. }\end{array}$ \\
\hline $\mathbf{C}_{i t}$ & $\begin{array}{l}\text { Cash flows are calculate as operating activities per-share minus investing } \\
\text { activities per-share. }\end{array}$ \\
\hline $\mathbf{A}_{i t}$ & Accruals are calculate as profit after tax per-share minus cash flows \\
\hline $\mathbf{r}_{i t+1}$ & $\begin{array}{l}\text { Magnitude adjusted buying and selling stocks returns were used to compute } \\
\text { excess return. First, average stock returns on yearly bases (sum of all } \\
\text { fifty-two weeks divided by fifty-two to make annual return) was computed } \\
\text { then by using market caps of same firms excess return (i.e., minus stock } \\
\text { returns of firms having same market caps) was computed. In order to cover } \\
\text { the aspects of missing delisting returns, due to liquidation if delisting occur, } \\
\text { delisting returns scale was set at -30 percent to +30 percent for PSX firms } \\
\text { (Shumway 1997; Shumway 1999). Stock returns are calculated on yearly } \\
\text { bases by taking weekly data of each year and divide it by fifty-two weeks. } \\
\text { Market Caps portfolio are determined by fiscal year end prices of stocks and } \\
\text { its number of shares outstanding. }\end{array}$ \\
\hline
\end{tabular}

$\boldsymbol{I}\left(\boldsymbol{X}_{\boldsymbol{i t}}<\mathbf{0}\right) \quad$ Indicator variable $=1$ if Variable $_{i t}<0$; and 0 otherwise.

To arrange portfolio returns on annual bases. The sample was enclosed by including June and December fiscal yearly firms. In line with previous studies, the research sample was further limited by including only top-volume non-financial firms of PSX. The sample includes 50 firms yearly report with available earnings and its components over the period of 8 years from 2011-2018. 


\subsection{Descriptive Statistics}

Table 1 presents descriptive statistics. Previous studies show the empirical distributions of earnings and its components are same (Dechow et al. 2006). The earnings show a positive asymmetry with an average value of 0.092437 , while 10.25 percent of the observation reported positive earning. On average excess return, cash flows, accruals, market caps and stock returns are positive with their mean values. Excess returns are negatively correlated with accruals, earnings and market caps, they are positively correlated with cash flows and stock returns. Accruals are negatively correlated with excess returns, cash flows and stock returns, they are positively correlated with earnings and market caps. Cash flows are negatively correlated with accruals, they are positively correlated with excess returns, earnings, market caps and stock returns. Earnings are negatively correlated with excess returns and stock returns, they are positively correlated with accruals, cash flows and market caps. Market caps are negatively correlated with excess returns and stock returns, they are positively correlated with accruals, cash flows and earnings. Stock returns are negatively correlated with accruals and earnings, they are positively correlated with excess returns and cash flows. Parallel with previous results on stock return in an estimated manner, accruals are positively (negatively) correlated with one year ahead excess stock returns. Dependent variable are excess returns and independent variables are accruals, earnings, market caps, stock returns and indicator of profit firms. To check the impact of dependent variable on independent variables, results shows that excess returns has a positive correlation with accruals and stock returns, and has negative correlation with earnings, market caps and indicator of profit firms.

Table 1. Descriptive statistics

Panel A: Empirical results

\begin{tabular}{lccccccc} 
& $\boldsymbol{r}_{\boldsymbol{i t + 1}}$ & $\boldsymbol{C}_{\boldsymbol{i t}}$ & $\boldsymbol{A}_{\boldsymbol{i t}}$ & $\begin{array}{c}\boldsymbol{I}\left(\boldsymbol{X}_{\boldsymbol{i t}}\right. \\
<\mathbf{0})\end{array}$ & $\begin{array}{c}\text { Market } \\
\text { Caps }\end{array}$ & $\boldsymbol{X}_{\boldsymbol{i t}}$ & $\begin{array}{c}\text { Stock } \\
\text { Returns }\end{array}$ \\
\hline Mean & 0.000285 & 0.036125 & 0.056312 & 0.102500 & $5.60 \mathrm{E}+10$ & 0.092437 & 0.004492 \\
Median & $1.54 \mathrm{E}-05$ & 0.035019 & 0.042370 & 0.000000 & $1.93 \mathrm{E}+10$ & 0.083261 & 0.003288 \\
Maximum & 0.054940 & 0.928175 & 0.932064 & 1.000000 & $1.12 \mathrm{E}+12$ & 0.813779 & 0.046783 \\
Minimum & -0.042994 & -1.133729 & -0.662644 & 0.000000 & $1.38 \mathrm{E}+08$ & -0.233641 & -0.024440 \\
Std. Dev. & 0.012183 & 0.164930 & 0.152084 & 0.303685 & $1.19 \mathrm{E}+11$ & 0.096892 & 0.010121 \\
Skewness & 0.207488 & -0.895608 & 1.025285 & 2.621126 & 5.355179 & 1.015106 & 0.966895 \\
Kurtosis & 5.618206 & 12.66602 & 9.150619 & 7.870304 & 37.48443 & 10.45475 & 4.823223 \\
& & & & & & & \\
Jarque-Bera & 117.1201 & 1610.674 & 700.5824 & 853.3512 & 21731.46 & 994.9166 & 117.7281 \\
\hline
\end{tabular}


$\begin{array}{llllllll}\text { Probability } & 0.000000 & 0.000000 & 0.000000 & 0.000000 & 0.000000 & 0.000000 & 0.000000\end{array}$

$\begin{array}{llllllll}\text { Sum } & 0.114000 & 14.45007 & 22.52486 & 41.00000 & 2.24 \mathrm{E}+13 & 36.97493 & 1.796781\end{array}$

Sum Sq.

Dev.

$\begin{array}{lllllll}0.059222 & 10.85354 & 9.228733 & 36.79750 & 5.62 \mathrm{E}+24 & 3.745867 & 0.040874\end{array}$

$\begin{array}{llllllll}\text { Observations } & 400 & 400 & 400 & 400 & 400 & 400 & 400\end{array}$

\section{Panel B: Correlations}

\begin{tabular}{|c|c|c|c|c|c|c|c|}
\hline & $r_{i t+1}$ & $A_{i t}$ & $C_{i t}$ & $X_{i t}$ & $I\left(X_{i t}<0\right)$ & $\begin{array}{c}\text { Market } \\
\text { Caps }\end{array}$ & $\begin{array}{c}\text { Stock } \\
\text { Returns }\end{array}$ \\
\hline$r_{i t+1}$ & 1.000000 & -0.046353 & 0.030468 & -0.020894 & -0.025363 & -0.047264 & 0.227049 \\
\hline$A_{i t}$ & -0.046353 & 1.000000 & -0.816150 & 0.180375 & -0.100227 & 0.079919 & -0.192724 \\
\hline$C_{i t}$ & 0.030468 & -0.816150 & 1.000000 & 0.421150 & -0.214019 & 0.078117 & 0.167998 \\
\hline$X_{i t}$ & -0.020894 & 0.180375 & 0.421150 & 1.000000 & -0.521621 & 0.258413 & -0.016538 \\
\hline$I\left(X_{i t}<\mathbf{0}\right)$ & -0.025363 & -0.100227 & -0.214019 & -0.521621 & 1.000000 & -0.137745 & -0.029943 \\
\hline $\begin{array}{l}\text { Market } \\
\text { Caps }\end{array}$ & -0.047264 & 0.079919 & 0.078117 & 0.258413 & -0.137745 & 1.000000 & -0.127690 \\
\hline Returns & 0.227049 & -0.192724 & 0.167998 & -0.016538 & -0.029943 & -0.127690 & 1.000000 \\
\hline
\end{tabular}

Panel C: Panel Least Squares Regression of Pooled Data

\section{Dependent Variable: Excess return}

\begin{tabular}{llll}
\hline Variable & Coefficient & t-Statistic & Prob. \\
\hline Accruals & 0.00272 & 0.58769 & 0.5571 \\
\hline Earnings & -0.0128 & -1.1923 & 0.234 \\
\hline Market Caps & $-2.55 \mathrm{E}-15$ & -0.141 & 0.888 \\
\hline Stock returns & 0.43243 & 5.42046 & 0 \\
\hline$I\left(X_{i t}<0\right)$ & -0.001 & -0.364 & 0.7161 \\
\hline C & -0.0004 & -0.2428 & 0.8083 \\
\hline R-squared & 0.19622 & & \\
\hline
\end{tabular}




\begin{tabular}{ll}
\hline Adjusted R-squared & 0.05115 \\
\hline F-statistic & 1.35263 \\
\hline Prob(F-statistic) & 0.05135 \\
\hline Durbin-Watson stat & 2.43133 \\
\hline
\end{tabular}

Effects Specification: Cross-section fixed, Period fixed (dummy variables).

This table presents descriptive statistics, correlations and panel regression of pooled data of following variables, earnings( $\left.X_{i t}\right)$, One year ahead Excess Return $\left(r_{i t+1}\right)$, free cash flows $\left(C_{i t}\right)$, market capitalization, accruals $\left(A_{i t}\right)$, stock return and the indicator variable of profit firm variable $I\left(X_{i t}<0\right)$. Panel A presents descriptive statistics. Panel B shows Correlations and Panel $\mathrm{C}$ shows Panel regression of pooled data. All definitions of variable are discussed in Appendix. The Sample includes 50 firms over a period of 8 years from 2011-2018.

\section{Re-evaluating the Accruals Anomaly}

Investigating previous differences in accrual's anomaly across non-financial loss and profit firms. Sloan's (1996) strategy used for trading of portfolio used in this sample. Sorted out the firm year-wise t from 2011-2018 into decile portfolio's basis on the yearly cross-sectional data of accruals. Year wise equal-weighted excess stock returns for each portfolio gained over the consecutive year $\mathrm{t}+1$ (i.e. minus stock returns of firms having similar market caps) was calculated. By following, the average values of accruals and excess stock returns then distribute them into decile portfolio was taken as shown in tables. Table 2 shows Time-series distribution of decile portfolios of excess stock returns and accruals. First of all, a significant difference in the total average value of accruals over company's portfolio was noticed, which varies from -0.0325 lowest accruals to 0.1458 higher accruals in decile method. In line with the previous results, negative relationship was observed between excess stock returns one year ahead and accruals. Switching from lower to higher accruals portfolio, one year ahead excess return decreases from 0.62 percent for the lowest decile portfolio to -0.46 percent for the high decile portfolio. Long position and short position firms with low and high accruals follows a trading strategy results in an average hedge return of 1.08 percent. Same these steps are followed on year wise distribution of decile portfolios of accruals and excess stock returns. Hedge return calculated in 2011 is 2.36 percent, 4.24 percent in 2012, 2.94 percent in 2013, 2.92 percent in $2014,2.81$ percent in $2015,2.87$ percent in $2016,2.28$ percent in 2017 and 3.03 percent in 2018.

Table 2 gives evidence of stock return in an estimated manner basis on accrual stock return. Parallel with Sloan trading strategy (1996), it seems that investors underestimate (undervalue) firms with low accruals and overestimate (overvalue) firms with high accruals. A risk basis is specific to the non-modeled factors of risk reduces with size of the accruals. On further comparison of results with konstantinidi et al. (2015) method shows that firms hedge return with low-high selling-buying accruals is larger when a wider range of conditions is used - a 


\section{Macrothink \\ International Journal of Accounting and Financial Reporting ISSN 2162-3082}

results is consistent with previous studies on the pricing of accruals (Richardson et al. 2005;

Dechow et al. 2011).

Table 2. The Accruals anomaly

Consecutive Excess returns and Accruals

Time-series distribution of Deciles portfolios of excess stock returns and accruals

Complete Sample of Non-Financial Loss and Profit firms

2011

\begin{tabular}{ccc} 
Deciles & $\boldsymbol{A}_{\boldsymbol{i t}}$ & $\boldsymbol{r}_{\boldsymbol{i t + 1}}$ \\
\hline low & $\mathbf{- 0 . 0 7 1 4 1 0 0 5}$ & $\mathbf{1 . 1 5 \%}$ \\
2 & 0.00378726 & $0.80 \%$ \\
3 & 0.02183858 & $0.56 \%$ \\
4 & 0.04979317 & $0.21 \%$ \\
5 & 0.08409676 & $-0.01 \%$ \\
6 & 0.09740374 & $-0.17 \%$ \\
7 & 0.13856319 & $-0.37 \%$ \\
8 & 0.16678435 & $-0.89 \%$ \\
high & $\mathbf{0 . 2 5 6 7 2 1 9}$ & $\mathbf{- 1 . 2 1 \%}$ \\
\hline
\end{tabular}

2012

\begin{tabular}{ccc} 
Deciles & $\boldsymbol{A}_{\boldsymbol{i t}}$ & $\boldsymbol{r}_{\boldsymbol{i t + 1}}$ \\
\hline low & $\mathbf{- 0 . 0 9 5 7 3 2 4 5}$ & $\mathbf{1 . 9 7 \%}$ \\
2 & -0.06649132 & $1.17 \%$ \\
3 & -0.04024536 & $0.48 \%$ \\
4 & -0.00534365 & $0.22 \%$ \\
5 & 0.012346457 & $0.06 \%$ \\
6 & 0.031038506 & $-0.38 \%$ \\
7 & 0.05847067 & $-0.69 \%$ \\
8 & 0.094359064 & $-1.39 \%$ \\
$\mathbf{h i g h}$ & $\mathbf{0 . 2 0 6 5 4 2 5 2 5}$ & $\mathbf{- 2 . 2 7 \%}$ \\
\hline
\end{tabular}


2013

\begin{tabular}{ccc} 
Deciles & $\boldsymbol{A}_{\boldsymbol{i t}}$ & $\boldsymbol{r}_{\boldsymbol{i t + 1}}$ \\
\hline low & $\mathbf{- 0 . 1 6 4 6 7 1 7 8}$ & $\mathbf{1 . 6 2 \%}$ \\
2 & -0.119409583 & $1.31 \%$ \\
3 & -0.066963458 & $0.91 \%$ \\
4 & -0.035076658 & $0.54 \%$ \\
5 & -0.004512016 & $-0.02 \%$ \\
6 & 0.004020118 & $-0.18 \%$ \\
7 & 0.025134546 & $-0.45 \%$ \\
8 & 0.062846219 & $-0.86 \%$ \\
high & $\mathbf{0 . 1 4 0 3 5 3 9 5 7}$ & $\mathbf{- 1 . 3 2 \%}$ \\
\hline
\end{tabular}

2014

\begin{tabular}{ccc} 
Deciles & $\boldsymbol{A}_{\boldsymbol{i t}}$ & $\boldsymbol{r}_{\boldsymbol{i t + 1}}$ \\
\hline low & $\mathbf{- 0 . 0 9 8 7 0 4 1 4 5}$ & $\mathbf{1 . 6 6 \%}$ \\
2 & -0.052192655 & $0.78 \%$ \\
3 & -0.024178789 & $0.58 \%$ \\
4 & 0.015660559 & $0.17 \%$ \\
5 & 0.05472487 & $-0.12 \%$ \\
6 & 0.081471542 & $-0.33 \%$ \\
7 & 0.12486116 & $-0.66 \%$ \\
8 & 0.16464589 & $-0.75 \%$ \\
high & $\mathbf{0 . 2 1 6 6 2 4 5 0 5}$ & $\mathbf{- 1 . 2 6 \%}$ \\
\hline
\end{tabular}

2015

\begin{tabular}{ccc} 
Deciles & $\boldsymbol{A}_{\boldsymbol{i t}}$ & $\boldsymbol{r}_{\boldsymbol{i t + 1}}$ \\
\hline low & $\mathbf{- 0 . 1 2 2 1 0 7 3 1 6}$ & $\mathbf{1 . 2 0 \%}$ \\
2 & -0.065634167 & $0.97 \%$ \\
3 & -0.041418142 & $0.61 \%$ \\
4 & -0.003905988 & $0.16 \%$ \\
5 & 0.020516609 & $-0.16 \%$
\end{tabular}




\begin{tabular}{ccc}
6 & 0.066577854 & $-0.33 \%$ \\
7 & 0.089029078 & $-0.56 \%$ \\
8 & 0.128769905 & $-0.73 \%$ \\
high & $\mathbf{0 . 2 2 7 8 2 3 3 8 4}$ & $\mathbf{- 1 . 6 1 \%}$ \\
\hline $\mathbf{2 0 1 6}$ & Hedge Return & $\mathbf{2 . 8 1 \%}$ \\
\hline Deciles & $\boldsymbol{A}_{\text {it }}$ & \\
\hline low & $\mathbf{- 0 . 1 0 3 1 2 1 6 4 4}$ & $\boldsymbol{r}_{\boldsymbol{i t + 1}}$ \\
\hline 2 & -0.050525196 & $\mathbf{1 . 4 6 \%}$ \\
3 & -0.021476162 & $0.98 \%$ \\
4 & 0.015323966 & $0.44 \%$ \\
5 & 0.034002347 & $0.21 \%$ \\
6 & 0.066173158 & $0.01 \%$ \\
7 & 0.103294074 & $-0.17 \%$ \\
8 & 0.155443986 & $-0.46 \%$ \\
high & $\mathbf{0 . 2 6 0 1 3 1 9 8}$ & $-0.65 \%$ \\
& $\mathbf{H e d g e ~ R e t u r n}$ & $\mathbf{- 1 . 4 1 \%}$ \\
\hline & & $\mathbf{2 . 8 7 \%}$ \\
\hline
\end{tabular}

2017

\begin{tabular}{ccc} 
Deciles & $\boldsymbol{A}_{\boldsymbol{i t}}$ & $\boldsymbol{r}_{\boldsymbol{i t + 1}}$ \\
\hline low & $\mathbf{- 0 . 0 6 8 1 2 2 2 7 3}$ & $\mathbf{1 . 2 6 \%}$ \\
2 & -0.027682815 & $0.85 \%$ \\
3 & -0.000911835 & $0.53 \%$ \\
4 & 0.048801414 & $0.28 \%$ \\
5 & 0.07577202 & $0.04 \%$ \\
6 & 0.110672012 & $-0.18 \%$ \\
7 & 0.144229988 & $-0.46 \%$ \\
8 & 0.174709813 & $-0.86 \%$ \\
high & $\mathbf{0 . 2 2 0 7 0 4 1 0 1}$ & $\mathbf{- 1 . 0 2 \%}$ \\
\hline
\end{tabular}

2018

Deciles

$A_{i t}$

$r_{i t+1}$ 


\begin{tabular}{|c|c|c|}
\hline low & -0.068122273 & $1.26 \%$ \\
\hline 2 & 0.017631161 & $0.74 \%$ \\
\hline 3 & 0.037961475 & $0.42 \%$ \\
\hline 4 & 0.048328579 & $0.32 \%$ \\
\hline 5 & 0.092220116 & $0.11 \%$ \\
\hline 6 & 0.117454809 & $-0.11 \%$ \\
\hline 7 & 0.144967329 & $-0.34 \%$ \\
\hline 8 & 0.188883102 & $-0.57 \%$ \\
\hline \multirow[t]{2}{*}{ high } & 0.331162176 & $-1.77 \%$ \\
\hline & Hedge Return & $3.03 \%$ \\
\hline \multicolumn{3}{|c|}{$\begin{array}{l}\text { This table presents time-series distribution of decile portfolios of one year ahead excess } \\
\text { return } \\
\text { and yearly cross sectional data of accruals. This table further explains long position and short } \\
\text { position firms with low and high accruals follow a trading strategy results in an hedge returns. } \\
\text { All definitions of variable are discussed in Appendix. The Sample includes } 50 \text { firms over a } \\
\text { period of } 8 \text { years from 2011-2018. }\end{array}$} \\
\hline
\end{tabular}

\section{Average Time-series distribution}

Average Time-series distribution of Deciles portfolios of excess stock returns and accruals

Complete Sample of Non- Financial Loss and Profit firms

\begin{tabular}{ccc} 
Deciles & $\boldsymbol{A}_{\boldsymbol{i t}}$ & $\boldsymbol{r}_{\boldsymbol{i t + 1}}$ \\
\hline low & $\mathbf{- 0 . 0 3 2 5 3 7 5 6 4}$ & $\mathbf{0 . 6 2 \%}$ \\
& 0.009682257 & $0.36 \%$ \\
\hline & & \\
\hline & 0.029241958 & $0.23 \%$ \\
5 & 0.044060407 & $0.08 \%$ \\
6 & 0.063819942 & $-0.08 \%$ \\
7 & 0.07297565 & $-0.14 \%$ \\
& 0.07872106 & $-0.23 \%$
\end{tabular}


This table represents yearly average time-series distribution of decile portfolios of one year ahead excess return and cross sectional data of accruals. This table further explains long position and short position firms with low and high accruals follow a trading strategy results in an average hedge return. All definitions of variable are discussed in Appendix. The Sample comprises of 50 firms over a period of 8 years from 2011-2018.

\section{Significance of Profit Non-financial Firms}

10.25 percent of all the observation reported positive earnings in the current year. As, the question arises whether all sample of loss and profit non-financial firms are more likely to influence the outcome in regards to causes and magnitude of the accruals anomaly. This element arises the question in context of accrual anomaly, magnitude of accruals varies with the number of non-financial profit firms. In fact, Table 3 presents enough evidence that the magnitude of accruals increases with the number of profit non-financial firms, but not always in a similar fashion. The frequency of non-financial profit firms is 90 percent for the lowest decile of accrual portfolio and 0 percent of the high decile of accrual portfolio. Table 3 also represent frequencies of non-financial profit firms with positive accruals, positive earnings and positive free cash flows over decile's accrual portfolio. Looking over portfolio, the number of positive free cash flows is 0 percent for the lowest decile of accrual portfolio and 100 percent for the high decile of accrual portfolio was found. Consequently, sorted out the firms basis cash flow's sign would result in combination of loss and profit non-financial firms.

To overcome this issue, loss firms are presented in the lowest decile of accrual portfolio in the table 3 relative to high decile of accrual portfolio with regard to inferences in accrual anomaly by pooling non-financial loss and profit firms. To tabulate the data for wider comprehension, sign of earnings provides a mean to measure gain and loss information by targeting the free cash flows and the size of accrual. Next, the differences in the accrual anomaly over subsample of non-financial loss and profit firms was rechecked.

Table 3. Differences in profit frequency with accruals

Average Time-series distribution of Deciles portfolios of excess stock returns and accruals Complete Sample of Non-Financial Loss and Profit firms

\begin{tabular}{ccccc}
\hline Deciles & $\boldsymbol{A}_{\boldsymbol{i t}}$ & $\boldsymbol{I}\left(\boldsymbol{X}_{\boldsymbol{i t}}<\mathbf{0}\right)$ & $\boldsymbol{I}\left(\boldsymbol{A}_{i t}<\mathbf{0}\right)$ & $\boldsymbol{I}\left(\boldsymbol{C}_{\boldsymbol{i t}}<\mathbf{0}\right)$ \\
\hline Low & $\mathbf{- 0 . 0 3 2 5 4}$ & $\mathbf{9 0 . 0 0 \%}$ & $\mathbf{1 0 0 . 0 0 \%}$ & $\mathbf{0 . 0 0 \%}$ \\
2 & 0.009682 & $0.00 \%$ & $0.00 \%$ & $0.00 \%$
\end{tabular}




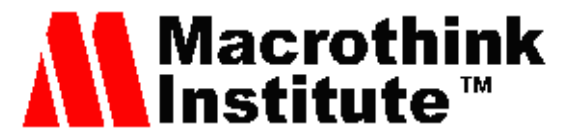

International Journal of Accounting and Financial Reporting ISSN 2162-3082 2020, Vol. 10, No. 3

\begin{tabular}{ccccc}
3 & 0.029242 & $0.00 \%$ & $0.00 \%$ & $0.00 \%$ \\
4 & 0.04406 & $0.00 \%$ & $0.00 \%$ & $0.00 \%$ \\
5 & 0.06382 & $0.00 \%$ & $0.00 \%$ & $0.00 \%$ \\
6 & 0.072976 & $0.00 \%$ & $0.00 \%$ & $0.00 \%$ \\
7 & 0.078721 & $0.00 \%$ & $0.00 \%$ & $100.00 \%$ \\
8 & 0.095327 & $0.00 \%$ & $0.00 \%$ & $100.00 \%$ \\
high & $\mathbf{0 . 1 4 5 8 5 6}$ & $\mathbf{0 . 0 0 \%}$ & $\mathbf{0 . 0 0 \%}$ & $\mathbf{1 0 0 . 0 0 \%}$ \\
\hline
\end{tabular}

This table presents average time-series distribution of decile portfolios of accruals and positive frequencies of earnings, accruals and free cash flows based on yearly cross sectional data of accruals. All definitions of variable are discussed in Appendix. The Sample comprises of 50 firms over a period of 8 years from 2011-2018.

\section{Differences in the Accrual Anomaly Across Subsample of Non-financial Loss and Profit Firms}

Table 4 information reveals that subsample of non-financial loss and profit firms basis on the portfolio of accruals and excess return. Subsample of loss and profit firms are sort out on the basis of sign of profit after tax (net income) reporting in t. In table 4, we again use Sloan's (1996) strategy of trading portfolios, adjusted to the reporting sign of earnings. Profit firms are sorted out on positive signs of reporting earnings and loss firms are sorted out on negative signs of reporting earnings. For each year, sorted out profit firms into decile portfolio basis on the yearly accrual cross-sectional order. While there are only 45 firms in profit firms subsample. So, decile portfolios are easily apply on it, but not in the case of loss firms. Loss firms are only 5 in the subsample. Sorted out loss firms into quartile portfolio. Then separately for both profit and loss firms, every year equal weighted average excess return was calculated for each portfolio gained over the consecutive year $t+1$.

Table 4 including panels (A and B) shows distribution of decile portfolios of average excess returns and accruals of non-financial loss and profit firms in a time series manner. Panel (A) focuses on profit non-financial firms ( 45 observation) shows that average excess returns falls from 0.60 percent for the lowest decile of accrual portfolio to -0.47 percent for the high decile of accrual portfolio. Long and short position in high and low accrual non-financial firms follows a trading strategy that results in an average hedge return of 1.07 percent. Moving to Panel (B), focuses on loss non-financial firms (5 observation) shows that average excess returns fall from -0.01 percent for the lowest decile of accrual portfolio to 0.64 percent for the high decile of accrual portfolio, that results in an average hedge return of 0.65 percent.

As mentioned in first section, in the persistence of accruals anomaly, naive earning fixation means that investors are more inclined to overvalue the presence of accruals especially in profit years. In parallel with Konstantinidi et al. (2015), the study reached to a conclusion that the subsample of Profit non-financial firms undergoes accrual anomaly. 
Table 4. The accrual anomaly: Differences in samples of non-financial loss and profit firms

Panel A: Sample of non-financial profit firms (45 firms).

Average Time-series distribution of Deciles portfolios of excess stock returns and accruals Subsample of Non-Financial Profit firms

\begin{tabular}{ccc}
\hline Deciles & $\boldsymbol{A}_{\boldsymbol{i t}}$ & $\boldsymbol{r}_{\boldsymbol{i t + 1}}$ \\
\hline low & $\mathbf{- 0 . 0 3 0 8 2 5 1 2 2}$ & $\mathbf{0 . 6 0 \%}$ \\
2 & 0.01461597 & $0.36 \%$ \\
3 & 0.035314942 & $0.14 \%$ \\
4 & 0.054438468 & $-0.02 \%$ \\
5 & 0.06541477 & $-0.09 \%$ \\
6 & 0.075157146 & $-0.19 \%$ \\
7 & 0.080393993 & $-0.26 \%$ \\
8 & 0.095326934 & $-0.31 \%$ \\
high & $\mathbf{0 . 1 4 1 5 8 6 2 6 4}$ & $\mathbf{- 0 . 4 7 \%}$ \\
\hline
\end{tabular}

\section{Panel B: Sample of non-financial loss firms ( 5 firms).}

Average Time-series distribution of Quartiles portfolios of excess stock returns and accruals Subsample of Non-Financial Loss firms

\begin{tabular}{ccc}
\hline Quartiles & $\boldsymbol{A}_{i t}$ & $\boldsymbol{r}_{\boldsymbol{i t + 1}}$ \\
\hline low & $\mathbf{- 0 . 0 3 9 6 2 3 2 1 8}$ & $\mathbf{- 0 . 0 1 \%}$ \\
2 & 0.009024593 & $0.31 \%$ \\
High & $\mathbf{0 . 0 9 4 4 0 9 6 6 1}$ & $\mathbf{0 . 6 4 \%}$ \\
\hline & Hedge Return & $\mathbf{0 . 6 5 \%}$ \\
\hline
\end{tabular}

This table presents yearly average time-series distribution of decile portfolios of one year ahead excess return and cross sectional data of accruals separately for non-financial loss and Profit firms. This table further explains long position and short position firms with low and high accruals follow a trading strategy results in an average hedge return. Non-financial firms are recognized on the sign of profit after taxes reported in time period $t$. All definitions of variable are discussed in Appendix. The Sample includes 50 firms over a period of 8 years from 2011-2018. 


\section{Conclusion}

This paper concludes that to the extent transaction-based anomaly reproduces incorrect prices, market failure is based on future prediction of accrual for profit-oriented companies rather than naively generating profits from investors. In fact, accrual anomaly, perhaps represents the variation in the premium of risk variable, such difference would seems to be important for non-financial profit firms.

Firms were sorted out on the basis of the presented earnings sign, study finding point out that although accrual anomaly expands over non-financial loss and profit firms, it is more pronounced in profit firms. The non-financial profit firms; average hedge return from buy/sell low/high accruals is 1.07 percent, while non-financial loss firms; buy/sell low/high accruals is 0.65 percent.

This study has reported accruals anomaly as the variation among earnings minus cash flows, i.e. auto sum of all activities of cash flow from operating and investing that are mentioned in the in the account of cash flows. When accruals compared with the cash flows taken from operating activities, free cash flows coincided with the flow in profits and consequential, the variation among earnings minus free cash flows gives a more detailed analysis of earnings quality and accrual.

Overall evidence lies in the favor of profit firms which are parallel with accrual mispricing: investors tend to partially anticipate the persistence in cash flows and accruals asymmetrically when they do not naively fixate on future earnings, which results in stock mispricing. The evidence highlighted in this paper pointed out that accrual across loss and profit generating non-financial firm's anomaly is more susceptible to accrual component of earning. In terms of accrual and alternative explanation of loss and gain, in contrast to Sloan et al, mostly that accrual anomaly is more important in terms of profit firms (Richardson et al. 2005; Dechow et al. 2011; Dechow et al 1995).

The practical implication of asymmetric timely loss recognition is proved to be dynamic in financial reporting to reduce the information asymmetry that might be beneficial in reducing the agency's cost and timely termination of projects (companies that will become unprofitable in the near future). In fact, information asymmetry needs to be more precise in revealing the firm's performance by targeting the accruals and stock returns.

We conclude that timely expense recognition of revenue generated in terms of losses relative to the profit through negative accrual items is dependent on accrual and stock return which plays a vital role in determining the performance of the firms over a period of economic gain. Our findings are parallel with Konstandini et al (2015), accrual anomaly and hedge return are stronger for non-financial profit firms whereas negative for loss firms. The evidence shows that the interpretation of accrual anomaly in the context of loss and profit companies is more susceptible to the magnitude of accrual component of earning.

Due to the traditional accounting identities, the wider analysis of the accruals are simplified into various parts, including changes in non-cash current assets (i.e. the variation between changes in current assets minus changes in current operational liabilities), the changes in net 
operational assets (i.e. the variation between the changes in operational asset minus the changes in operational liabilities). Future researches need to be carried out on the exploration of the sources of accrual overestimation over loss and profit firms.

\section{References}

Aier, J. K., Chen, L., \& Pevzner, M. (2014). Debtholders' demand for conservatism: Evidence from changes in directors' fiduciary duties. Journal of Accounting Research, 52(5), 993-1027. https://doi.org/10.1111/1475-679x.12062

Artikis, P. G., \& Papanastasopoulos, G. A. (2019). Asymmetries in the persistence and pricing of cash flows: Evidence from the United Kingdom. The Journal of Economic Asymmetries, 19(C), 1-1. https://doi.org/10.1016/j.jeca.2019.e00113

Asare, K. (2019). Earnings Persistence and Levels of the Accrual Ratio and Discretionary Accruals. Journal of Business, Economics and Technology.

Ball, R. (2001). Infrastructure requirements for an economically efficient system of public financial reporting and disclosure. Brookings-Wharton Papers on Financial Services, 2001(1), 127-169. https://doi.org/10.1353/pfs.2001.0002

Ball, R., \& Shivakumar, L. (2005). Earnings quality in UK private firms: comparative loss recognition timeliness. Journal of Accounting and Economics, 39(1), 83-128. https://doi.org/10.1016/j.jacceco.2004.04.001

Ball, R., \& Shivakumar, L. (2006). The role of accruals in asymmetrically timely gain and loss recognition. Journal of Accounting Research, 44(2), 207-242. https://doi.org/10.1111/j.1475-679x.2006.00198.x

Ball, R., Kothari, S. P., \& Nikolaev, V. V. (2013). Econometrics of the Basu asymmetric timeliness coefficient and accounting conservatism. Journal of Accounting Research, 51(5), 1071-1097. https://doi.org/10.1111/1475-679x.12026

Ball, R., Kothari, S. P., \& Robin, A. (2000). The effect of international institutional factors on properties of accounting earnings. Journal of Accounting and Economics, 29(1), 1-51. https://doi.org/10.1016/s0165-4101(00)00012-4

Basu, S. (1997). The conservatism principle and the asymmetric timeliness of earnings 1. Journal of Accounting and Economics, 24(1), 3-37. https://doi.org/10.1016/s0165-4101(97)00014-1

Bliss, J. H. (1924). Management through accounts. Ronald Press Company.

Bradshaw, M. T. Richardson, S., \& Sloan, R. (2001), Do analysts and auditors use Information in accruals?. Journal of Accounting Research, 39(1), 45-74. https://doi.org/10.1111/1475-679x.00003

Campbell, J. Y., \& Vuolteenaho, T. (2004). Bad beta, good beta. American Economic Review, 94(5), 1249-1275. https://doi.org/10.1257/0002828043052240 


\section{$\triangle$ Macrothink}

International Journal of Accounting and Financial Reporting

ISSN 2162-3082

Dechow, P. M., \& Ge, W. (2006). The persistence of earnings and cash flows and the role of special items: Implications for the accrual anomaly. Review of Accounting Studies, 11(2-3), 253-296. https://doi.org/10.1007/s11142-006-9004-1

Dechow, P. M., Khimich, N. V., \& Sloan, R. G. (2011). The accrual anomaly. In L. Zacks (Ed.), The Handbook of Equity Market Anomalies: Translating Market Inefficiencies Into Effective Investment Strategies (Chap. 2). https://doi.org/10.1002/9781119200697.ch2

Dechow, P. M., Sloan, R. G., \& Sweeney, A. P. (1995). Detecting earnings management. Accounting Review, 193-225.

Devine, C. T. (1963). The rule of conservatism reexamined. Journal of Accounting Research, 127-138. https://doi.org/10.2307/2489851

Dutta, S., Patatoukas, P. N., \& Fund, F. (2016). Asymmetric Timeliness Estimates of Conditional Conservatism: Separating Accounting from Economics. https://doi.org/10.2139/ssrn.2615205

Fama, E. F., \& French, K. R. (1993). Common risk factors in the returns on stocks and bonds. Journal of Financial Economics, 33(1), 3-56. https://doi.org/10.1016/0304-405x(93)90023-5

Fama, E. F., \& MacBeth, J. D. (1973). Risk, return, and equilibrium: Empirical tests. Journal of Political Economy, 81(3), 607-636. https://doi.org/10.1086/260061

Financial Accounting Standards Board (FASB). (1975). Accounting for Contingencies. Statement of Financial Accounting Standards No. 5, FASB, Norwalk, CT.

Financial Accounting Standards Board (FASB). (2009a). Inventory. Accounting Standards Codification 330, FASB, Norwalk, CT.

Financial Accounting Standards Board (FASB). (2009b). Intangibles-goodwill and other. Accounting Standards Codification 350, FASB, Norwalk, CT.

Financial Accounting Standards Board (FASB). (2009c). Property, plant, and equipment. Accounting Standards Codification 360, FASB, Norwalk, CT.

Green, J., Hand, J. R., \& Soliman, M. T. (2011). Going, going, gone? The apparent demise of the accruals anomaly. Management Science, 57(5), 797-816. https://doi.org/10.1287/mnsc.1110.1320

Hayn, C. (1995). The information content of losses. Journal of Accounting and Economics, 20(2), 125-153. https://doi.org/10.1016/0165-4101(95)00397-2

Jensen, M. C. (1996). Agency costs of free cash flow, corporate finance, and takeovers. The American Economic Review, 76(2), 323-329. https://doi.org/10.1017/cbo9780511609435.005

Khan, M. (2008). Are accruals mispriced? Evidence from tests of an intertemporal capital asset pricing model. Journal of Accounting and Economics, 45(1), 55-77. https://doi.org/10.1016/j.jacceco.2007.07.001 


\section{Macrothink}

International Journal of Accounting and Financial Reporting

ISSN 2162-3082

2020, Vol. 10, No. 3

Konstantinidi, T., Kraft, A., \& Pope, P. F. (2016). Asymmetric persistence and the market pricing of accruals and cash flows. Abacus, 52(1), 140-165. https://doi.org/10.1111/abac.12072

Mishkin, F. S. (1983). A Rational Expectations Approach to Macroeconometrics. The National Bureau of Economic Research, 9-43. https://doi.org/10.7208/chicago/9780226531922.001.0001

Papanastasopoulos, G. A. (2014). Accounting accruals and stock returns: Evidence from European equity markets. European Accounting Review, 23(4), 729-768. https://doi.org/10.1080/09638180.2014.882264

Papanastasopoulos, G. A. (2019). Bloated balance sheets and stock returns: Asymmetries between profit and loss firms. Economics and Business Letters, 8(1), 53-61. https://doi.org/10.17811/ebl.8.1.2019.53-61

Patatoukas, P. N. (2016, March). Asymmetrically timely loss recognition and the accrual anomaly. Abacus. https://doi.org/10.1111/abac.12063

Patatoukas, P. N., \& Thomas, J. K. (2016). Placebo tests of conditional conservatism. The Accounting Review, 91(2), 625-648. https://doi.org/10.2308/accr-51179

Pincus, M., Rajgopal, S., \& Venkatachalam, M. (2007). The accrual anomaly: International evidence. The Accounting Review, 82(1), 169-203. https://doi.org/10.2308/accr.2007.82.1.169

Richardson, S. A., Sloan, R. G., Soliman, M. T., \& Tuna, I. (2005). Accrual reliability, earnings persistence and stock prices. Journal of Accounting and Economics, 39(3), 437-485. https://doi.org/10.1016/j.jacceco.2005.04.005

Shumway, T. (1997). The delisting bias in CRSP data. The Journal of Finance, 52(1), 327-340. https://doi.org/10.1111/j.1540-6261.1997.tb03818.x

Shumway, T., \& Warther, V. A. (1999). The delisting bias in CRSP's Nasdaq data and its implications for the size effect. The Journal of Finance, 54(6), 2361-2379. https://doi.org/10.1111/0022-1082.00192

Sloan, R. G. (1996). Do stock prices fully reflect information in accruals and cash flows about future earnings?. Accounting Review, 289-315.

Srivastava, A., Sunder, S., \& Tse, S. (2015). Timely loss recognition and termination of unprofitable projects. China Journal of Accounting Research, 8(3), 147-167. https://doi.org/10.1016/j.cjar.2015.05.001

Sterling, R. R. (1970). The Theory of the Measurement of Enterprise Income. University of Kansas Press, Lawrence, KS.

Supattarakul, S. (2013). The Earnings Persistence and the Market Pricing of Cash Flows, Normal and Abnormal Accruals: Thailand's Capital Markets. Working Paper at Thammasat Business School. 


\section{Macrothink}

International Journal of Accounting and Financial Reporting ISSN 2162-3082

Watts, R. L., \& Zimmerman, J. L. (1986). Positive accounting theory. Prentice-Hall, Toronto. Wu, J., Zhang, L., \& Zhang, X. F. (2010). The q-theory approach to understanding the accrual anomaly. Journal of Accounting Research, 48(1), 177-223. https://doi.org/10.1111/j.1475-679x.2009.00353.x

Xie, H. (2001). The mispricing of abnormal accruals. The Accounting Review, 76(3), 357-373. https://doi.org/10.2308/accr.2001.76.3.357

\section{Copyright Disclaimer}

Copyright for this article is retained by the author(s), with first publication rights granted to the journal.

This is an open-access article distributed under the terms and conditions of the Creative Commons Attribution license (http://creativecommons.org/licenses/by/4.0/) 